\title{
International Capital Flows Within the European Monetary Union: Increasing Economic Divergence Between the Centre and the Periphery
}

\author{
Sergio Rossi*
}

This paper aims at investigating some neglected consequences of free capital mobility in the Euro area. The approach we use in this work is based on the bookkeeping nature of money, which shows that capital - in the form of bank deposits - is mobile within a currency area but actually immobile between different monetary spaces. Within the Euro area both short-and long-term investments are directed into those economies where the return on investment is highest, a magnitude that is positively correlated with the rate of real growth. If so, then economic divergence might increase between member countries of the European Monetary Union (EMU), giving rise thereby to a higher rate of unemployment in those member countries that suffer from net capital outflows, to the benefit of some other countries in the same area.

JEL classifications: $E_{3}, E_{6}, F_{2 I}, F_{3} 6$

Keywords: capital mobility, economic divergence, monetary policy, monetary union

* University of Fribourg, Switzerland. The author would like to thank Angel Asensio, Oscar De Juan, Eckhard Hein, Basil Moore, Thomas Palley, Heinz-Peter Spahn, Henri Sterdyniak, and two anonymous referees for their helpful comments and suggestions. Research assistance by Entela Myftari and Christian Laszewski is also gratefully acknowledged. The usual disclaimer applies.

Correspondence Address:

Prof. Sergio Rossi, Ph.D., Chair of Macroeconomics and Monetary Economics, Department of Economics, University of Fribourg, Boulevard de Pérolles 90 (mailbox 22), $\mathrm{CH}-1700$ Fribourg, Switzerland, e-mail: sergio.rossi@unifr.ch

Received I5 Jan 2007, accepted 8 Jun 2007

(C) INTERVENTION 4 (2), 2007, 309-329 


\section{Introduction}

International capital flows have become a topic of hot debate all around the world in the last ten years or so, notably, as an aftermath of the East Asian financial crises (1997-1998). As a matter of fact, the last decade witnessed some important changes in exchange rate arrangements and in country-specific rules governing capital mobility. In parallel to these facts, academic and policy discussions have begun to concentrate on (a) the choice of the appropriate exchange rate regime to avoid exchange rate fluctuations and thereby financial instability sparked off by a currency turmoil, and (b) the role of capital account controls to reduce a country's vulnerability to speculation as well as currency crises. Indeed, as Stiglitz (2004: 57) notes, the financial crises of the late I990s and early years of the new millennium are partly, if not largely, attributable to capital account liberalisation. Now, capital account liberalisation is the area where there is the greatest disconnection between economic theory and actual events in the real world (Singh 2003). Proponents of neoclassical theory argue that the case for free capital flows is not different from that for free trade: the former could simply be regarded as a form of inter-temporal trade. In particular, Fischer (2004) argues in favour of free capital flows as this liberalisation will elicit a series of macroeconomic benefits that outweigh its costs: it would lead to global economic efficiency, allocation of world savings to those who are able to use them most productively, and would thereby increase social welfare.

In fact, several economists argue today that various types of capital flows differ in their cost and benefit characteristics (see e.g. Goldin/Reinert 2005 for analytical elaboration). Consequently, the economic impacts of capital flows do not readily lend themselves to any kind of generalisations. Instead, the cost and benefit characteristics of distinct types of capital flows ought to be considered. In this respect, and in light of the string of financial crises that occurred recently in East Asia, Latin America, Russia, and Turkey, a growing number of economists argue today that unfettered short-term capital flows can have a series of negative consequences, as these flows are often extremely volatile and unpredictable to a very large extent. These same economists, however, consider long-term capital flows, and in particular foreign direct investment (FDI), ${ }^{1}$ as being more stable and, therefore, beneficial for economic growth as well as for development. They suggest, therefore, that transition and emerging market economies ought to liberalise - at least in a first move, over the medium-to-long run - only long-term capital movements, while still controlling partially or wholly - short-term capital flows (see e.g. Edwards 1999, and the literature cited therein). The same holds for advanced economies, whose capital account transactions have already been fully liberalised, particularly between countries that participate to some form of regional economic and financial integration.

I According to the universally-adopted benchmark definition of FDI put forward by the Organisation for Economic Cooperation and Development (OECD), FDI is the category of cross-border investment made by an entity resident in one country to acquire at least ten percent of the equity capital of a firm operating in another country. 
This paper concentrates on the Euro area. It focuses on capital flows across the countries that fully participate in the EMU, considering the amount and direction of these flows within the single currency area. ${ }^{2}$ In fact, capital flows cannot trespass a currency area's borders: Capital being in the form of a bank deposit, and bank deposits being recorded in the balance sheet of the banking system issuing the monetary unit in which these deposits are labelled, there can be no capital flight from the banking system of the currency area that issues this monetary unit. The Euro area is therefore a closed monetary space, as is indeed the case for any currency area within which a single currency exists as a means of final payment between any two agents, the payer and the payee, who exchange real or financial items (bonds, stocks, options, and so on including foreign assets) through the debit and credit of bank deposits in the banking system that carries out the relevant payment. As a result, bank deposits are, always and everywhere, the monetary representation of any items that agents exchange, within or across a given currency area. Hence they measure total wealth existing in this area, as they subsume all categories of (real and financial) assets in the agents' portfolio - both in the private and in the public sector of the economy, as the mechanics of payments is the same, and does not depend on the personal identity of the payer or payee. The payee, as a matter of fact, is always credited with a bank deposit, which is the mark of payment finality in so far as the non-bank agents are concerned: The payee has thereby no further claim on the payer, who might reside in the same currency area or not. To be sure, if the payment concerns a cross-border transaction, that is to say, if it is across two currency areas, then the mark of payment finality remains within the banking system of the currency area in which the payer's bank resides. Indeed, the payee, or the bank in which s|he holds an account, is credited with a deposit in the banking system through which the payer settles her or his obligation. Note, however, that, for the currency area as a whole (including the general government sector as well as the private sector of the economy), the formation of income depends on production activities. Only these activities produce an income that is net for the whole currency area, and that cannot but be spent within this same area finally, although perhaps after a series of transactions on financial markets - which, nevertheless, cannot add any amount of wealth to the total income resulting from production in that area (see Rossi 2007: chapter 2 for analytical elaboration).

Now, in the case of the EMU, which is to date the largest multinational single-currency area, capital flows can trespass an EMU member country's borders, as either incoming or outgoing payments from or to another member country. For instance, when (say) a German importer pays for a real or financial item that $s$ he obtained from (say) Italy, the German banking system (hence Germany as a whole) loses a bank deposit, which is to be found in Italy (precisely within the Italian banking system, which records this deposit

2 Although capital flows associated with foreign trade, on the one hand, and capital flows associated with factor income resulting from the net-creditor or net-debtor position of a country, on the other hand, differ with respect to their rationale, they can be considered altogether as regards their underlying monetary definition, that is, bank deposits. This holds for FDI, too, as we shall explain later. 
in the bank account of the local exporter). By way of contrast, when a German importer pays for an item imported from (say) Poland, that is, a non-EMU member country, then the German banking system does not lose any monetary unit, although the bank deposit surrendered by the German importer is then owned by a non-resident, namely, the Polish bank through which the local exporter is finally paid in his/her own local currency. This reasoning also holds for capital account transactions, as every payment implies the debit of the payer and credit of the payee in the accounts of the paying bank, which resides in the (net) importing country.

Indeed, no bank deposit can leave the monetary system in which it is recorded. Thus, the debate on international capital flows is beside the point as far as it regards those monetary flows that are purported to exist between countries pertaining to two different currency areas. To repeat the key analytical point, any currency area is a closed monetary space: no single unit of money can actually leave the monetary system that issues it. If so, then Euro area member countries were better off before they abandoned their national currencies, as they were able to retain all capital formed within their domestic monetary economy of production. Indeed, when these countries disposed of their local currencies to enter into the single currency area, they ipso facto disposed - willingly or not - of the monetary barrier that mechanically protected their domestic economy from any capital flight, independently of the forms of behaviour of economic agents (residing or not in these countries). In fact, even if a resident of a currency area (say, country A) manages to hide a part of his or her capital by transferring it to a non-resident bank, that is to say, a bank residing in another currency area (say, country B), this cannot, and does not, affect the total sum of bank deposits that are recorded in the banking system of country A. It might affect, however, the fiscal stance of country A, but this is an issue that lies much beyond the scope of this paper and that we therefore put aside here.

The structure of the paper is as follows. The next section briefly provides the theoretical framework within which capital flows between and across different currency areas can be investigated consistently with the book-entry nature of money. The third section then considers the empirical evidence available so far with respect to capital movements between the member countries of the EMU, to explain why monetary union in Europe is in fact increasing economic divergence within Euroland. In light of this analysis, the last section concludes with some policy-oriented remarks.

\section{Capital Flows Between Different Currency Areas: A Real Issue?}

Capital flows within the Euro area, and particularly across its member countries, raise an issue that seems to have been downplayed, if not neglected, so far. This is worrying, so much so that this issue did not feature in those discussions that led to the ratification of the Maastricht Treaty on the European (Monetary) Union. Before addressing the EMU case, considering the causes as well as consequences of capital flows between its member countries, it is therefore important to define the conception of capital flows analytically. 
The concept of capital flight is usually considered literally, that is to say, as if capital ${ }^{3}$ can leave the monetary space in which it has been formed, to be at rest in some foreign currency area, where it can be "hidden « or invested depending on its holder's purposes and willingness to act. As noted, in fact, banks' double-entry book-keeping prevents any capital from fleeing the monetary space within which it originated, although, of course, its physical representations (real or financial assets) can move across two different monetary spaces and thereby leave their original currency area. To be sure, any amount that a bank's client in a given currency area transfers to the rest of the world remains deposited within the banking system of that same currency area, considered as a whole (Spahn 2006: 26Iff.). In other words, this means that monetary boundaries are "natural barriers" against capital movements, free capital flows being really possible only within a single currency area. This does not mean, nevertheless, that a financial asset, or a real asset like a picture of a famous painter, cannot be bought and held in a monetary space different from the currency area within which the relevant bank deposits are recorded. The point here is that, in order for a non-resident to buy this asset, this agent has to own a bank deposit in the country where the economic transaction will take place, and within whose banking system the relevant payment will be recorded through the double-entry book-keeping system of a bank. Clearly, this means that any real or financial asset has as its monetary counterpart a deposit somewhere in the banking system that makes it possible for the relevant payment to occur. Indeed, any payment being a transaction that involves two agents, their »initial endowments" simply change places as a result of the transaction: the object of the payment is eventually in the hands (or portfolio) of the buyer, while the means of payment (a bank deposit) is eventually in the ownership of the seller of the object exchanged and is notably recorded in the bank through which the payment is carried out. This shows, once again, that bank deposits, that is, the alter ego of any form of capital (real or financial), cannot leave the banking system of a given currency area, that is, the monetary space within which these deposits have been formed as a result of the working of the local monetary economy of production (Rossi 2007: chapters I-2).

Now, the logical impossibility for any bank deposit to leave the currency area in which it has been formed does not mean that capital cannot be invested in the rest of the world. The decision by a resident in country A to transfer (part of) his or her capital in the form

3 As Hicks (1974: 309) points out, "[i]f it is capital in the volume sense that is being measured, capital is physical goods; but in the value sense capital is not physical goods. It is a sum of values which may conveniently be described as a Fund«. Indeed, fixed capital, that is, those capital goods used by firms for the production of other goods, is the physical result of investment, which is funded by an amount of bank deposits, either owned by firms (retained profits) or borrowed by them through the banking system or the financial market. To be sure, firms borrow investment funds by selling financial claims. If so, any kind of financial assets (bonds, stocks, options, derivatives, and so on) is obtained through an expenditure of bank deposits, which are thus the necessary and sufficient condition for capital to exist, in either a financial or a real form. See Keynes (1936: 8I-82) for a restatement of the same conclusion, referring to the identity between saving and investment in a given currency area at any given point of time. 
of bank deposits to a different currency area (say, country B) means that this economic agent, in fact, converts his or her capital labelled in money A (MA) into an equivalent capital formed in country B and thus labelled in money B (MB). Investment of the latter capital in country B does not reduce the capital formed and available for investment in country A. The relevant deposit (say, of x MA) in country A's banking system is then owned by a non-resident, namely, a foreign bank (bank B), which resides in a different currency area (country B) (table I). ${ }^{4}$

\section{Table I: The Currency Area's Banking System as a Closed Monetary Space}

\begin{tabular}{l|ll}
\hline \multicolumn{3}{c}{$\begin{array}{c}\text { Bank A } \\
\text { (resident in country A) }\end{array}$} \\
\hline Assets & \multicolumn{1}{|c}{ Liabilities } \\
\hline & Deposit of client I & $-x$ MA \\
& Deposit of bank B & $+x$ MA \\
\hline
\end{tabular}

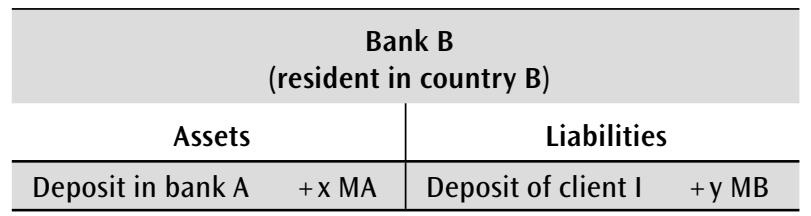

Table I shows that a resident in country A (client I) can transform a deposit in bank A into an equivalent deposit in bank $\mathrm{B}$ (assume that $\mathrm{x} \mathrm{MA}=\mathrm{y} \mathrm{MB}$ ). This resident can own thereby a financial capital, in the form of a bank deposit, formed in another country and currency area. This same agent can therefore spend and invest abroad a capital that $s \mid$ he owns in that foreign country. In fact, this agent (residing in country A) can decide to spend this foreign bank deposit (in country B's banking system) to pay for any imported items from that same country (see below). The same holds for bank B, of course. Now, if bank B spends

$4 \quad$ Note in passing that country B's banking system records the image of the bank deposit that remains in country A, which amounts to a duplication of country A's deposit (x MA) as pointed out by Rueff (1963: 323-324). If so, then any trade surplus of Euroland against, say, the United States implies that the latter does not lose any bank deposits, and that the image of these deposits that the Euro-area banking system records induces an inflationary pressure within Euroland, as these amounts are converted into euros and spent on Euro-area markets for produced output. Needless to note, these same amounts can be sold and bought on the foreign exchange market, giving rise to a net supply of or a net demand for the relevant currency, as a result of which exchange rates fluctuate and are indeed unpredictable, so as to induce speculation on the foreign exchange market. This is, in fact, an international monetary disorder that has to be eradicated by a structural reform of the international payment machinery, which could and should occur in the spirit of Keynes's proposal for an international settlement system (Keynes 1980). 
a deposit formed in country $A$ for purchasing firm $\mathrm{F}_{1}$ 's securities, this means that this firm obtains a bank loan, which it might use in order for it to finance an investment in the currency area of country A. If this firm resides in a different currency area (say, country B), the loan that it obtains through the sale of securities means that it operates a FDI within the currency area where the relevant capital originated (country A), to the benefit of a local seller of securities (firm $\mathrm{F}_{2}$ ) (table 2).

\section{Table 2: The Result of a Foreign Direct Investment in Country $A$}

\begin{tabular}{l|ll}
\hline \multicolumn{3}{c}{ Bank A } \\
(resident in country A) \\
\hline Assets & \multicolumn{2}{|c}{ Liabilities } \\
\hline & Deposit of bank B & $-\mathrm{x} \mathrm{MA}$ \\
& Deposit of firm $\mathrm{F}_{1}$ & $+\mathrm{x} \mathrm{MA}$ \\
& Deposit of firm $\mathrm{F}_{1}$ & $-\mathrm{x} \mathrm{MA}$ \\
& Deposit of firm $\mathrm{F}_{2}$ & $+\mathrm{x} \mathrm{MA}$ \\
\hline
\end{tabular}

\begin{tabular}{|c|c|c|}
\hline \multicolumn{3}{|c|}{$\begin{array}{c}\text { Bank B } \\
\text { (resident in country B) }\end{array}$} \\
\hline Assets & & Liabilities \\
\hline $\begin{array}{l}\text { Deposit in bank A } \\
\text { Credit to firm } F_{1}\end{array}$ & $\begin{array}{l}-x M A \\
+y M B\end{array}$ & \\
\hline
\end{tabular}

By contrast, if capital formed in country A is lent to an importer residing in country B, then the relevant bank deposit finances country B's imports from A, which means that a bank residing in country A pays the local exporter with an amount of bank deposits that are part of this country's national income. As a result, it is the net exporting country that finally pays for its own trade surplus, which is another point that is often overlooked in the literature (table 3, p. 316).

We notice in table 3 that a resident in country B (importer B) transforms a bank deposit in B's banking system (y MB) into an equivalent deposit in A's banking system (x MA) in order for this agent finally to pay for the item(s) $s$ he imports from A. As a result, the exporter (a resident in country A) is finally paid, as $s$ he holds a claim on a bank deposit in the banking system of the country where $s$ he resides. All in all, country B defined as a whole has paid for a net import with a bank deposit formed in country A: Production worth x MA has been imported in country B and finally paid with a deposit recorded in country A's banking system. The fact that this production (of A) is physically consumed in another currency area (country B) does not really matter for macroeconomic analysis. In fact, any exported item (a real good or service) is consumed in the country producing it, if one considers consumption as an economical rather than a physical action. Indeed, 


\section{Table 3: The Result of a Cross-Border Payment for Foreign Trade}

\begin{tabular}{|c|c|c|c|}
\hline \multicolumn{4}{|c|}{$\begin{array}{c}\text { Bank A } \\
\text { (resident in country A) }\end{array}$} \\
\hline \multicolumn{2}{|l|}{ Assets } & \multicolumn{2}{|l|}{ Liabilities } \\
\hline & & $\begin{array}{l}\text { Deposit of bank B } \\
\text { Deposit of importer B } \\
\text { Deposit of importer B } \\
\text { Deposit of exporter A }\end{array}$ & $\begin{array}{l}-x \text { MA } \\
+x \text { MA } \\
\text {-x MA } \\
+x \text { MA }\end{array}$ \\
\hline \multicolumn{4}{|c|}{$\begin{array}{l}\text { Bank B } \\
\text { (resident in country B) }\end{array}$} \\
\hline Assets & & Liabilities & \\
\hline Deposit in bank A & $-\mathrm{XMA}$ & Deposit of importer B & $-y M B$ \\
\hline
\end{tabular}

production being the action that integrates physical output into its numerical form (that is to say, money) as soon as the relevant wages are paid out by firms through banks to workers, consumption is an action that dissociates money from physical output: The former is destroyed by banks owing to the so-called reflux principle, ${ }^{5}$ while the latter is physically appropriated and consumed over time by those economic agents that purchased it on the market for produced goods, either within or outside their country of residence.

Be that as it may, the total sum of bank deposits - the form in which all capital exists $-{ }^{6}$ formed within a currency area cannot but remain within that area, owing to the book-entry nature of money as well as to the double-entry book-keeping system of banks. In a nutshell, capital is immobile between currency areas, but it is of course mobile within a given single-currency area, within which there exists a payment system headed by a settlement institution, which makes sure that interbank payments are finalised by the transfer of settlement balances in the form of central bank money (Rossi 2007: chapter 3). If so, then what can we say about capital mobility within the EMU? Let us address this question in the next section.

5 See Lavoie (1999) for an analysis of the reflux principle in the history of monetary thinking.

6 Recall that all capital (either real or financial) is subsumed under the relevant amount of bank deposits, which are recorded in the banking system (including the central bank) that issues the money unit in which this capital is measured as soon as it is formed (as a result of the workings of the local monetary economy of production, see above). The concept of capital flight refers therefore exclusively to bank deposits (bank notes are indeed the material representation of a deposit in the central bank issuing them, see Innes 1913). 


\section{Capital Flows Between the EMU Member Countries: Where Do We Stand?}

In a multinational currency area such as the EMU, which represents indeed a single and unified monetary space owing to the emission of a single European currency, capital - in the form of bank deposits - can move between its member countries freely. In particular, savings could flow from EMU countries with a relatively high propensity to save to member countries with favourable investment and earning opportunities, in line here with the Feldstein/Horioka (1980) hypothesis. In this connection, figures I and 2 (p. 318) show scatter plots of saving shares and investment shares in GDP in the EU-Is countries over two different time periods, that is, $1992-1998$ (the pre-EMU period) and $1999-2005$ (the first seven years of the EMU).

The I992-I998 data in figure I show a quite widespread spectrum of correlation between saving and investment across the EU-I5 member countries. In particular, countries with a relatively low saving-to-GDP ratio have also a relatively low investment-to-GDP ratio in comparison with countries having higher ratios. This might suggest that in this period capital was not mobile across countries, which could validate the theoretical explanation pointed out above with respect to the monetary barrier to capital flight that exists when a local currency subsists. By way of contrast, figure 2 shows a marked flattening for the relation between saving shares and investment shares in GDP, in particular for the core countries of the EMU, namely, Belgium, France, Germany, Italy, and the Netherlands: ${ }^{7}$ Despite their relatively different saving-to-GDP ratios, their investment share of GDP is similar over the period 1999-2005, that is, the EMU period for which data are available. Indeed, this is the relationship that one may expect to observe for countries with similar economies and perfect capital mobility (Coakley et al. 1998).

Now, to make this scattered empirical evidence more robust and to gain further insights into the actual direction of capital flows between the EMU member countries, we performed some calculations on GNP-to-GDP ratios for the EU-I2 excluding Ireland and Luxembourg. ${ }^{8}$ These ratios give an indication of whether a country owes to or earns from abroad a net factor income as a result of (past) capital flows. It is a proxy measure of the extent and direction of capital movements within the single currency area named after the euro, ${ }^{9}$ as we know from the reasoning made above that there can be no capital flows across a currency area's borders (hence any capital outflow from a EMU-member country is a capital inflow for another EMU-member country, and vice versa). Table 4 (p. 3I9) shows the percentage deviation from the EU-Io average of the GNP-to-GDP ratios for the relevant EMU member countries over the two periods considered in figures $\mathrm{I}$ and 2

8 We exclude Ireland and Luxembourg from the EU-I2 group (hence the EU-Io reference), as both these countries are quasi-offshore financial centres and their inclusion would thus distort the average. We thank one of the referees for bringing this point to our attention.

9 We borrow this methodology from the work of Bayoumi et al. (I999). 
Figure I: Saving and Investment Shares of GDP in the EU-IS Countries, I992-1998

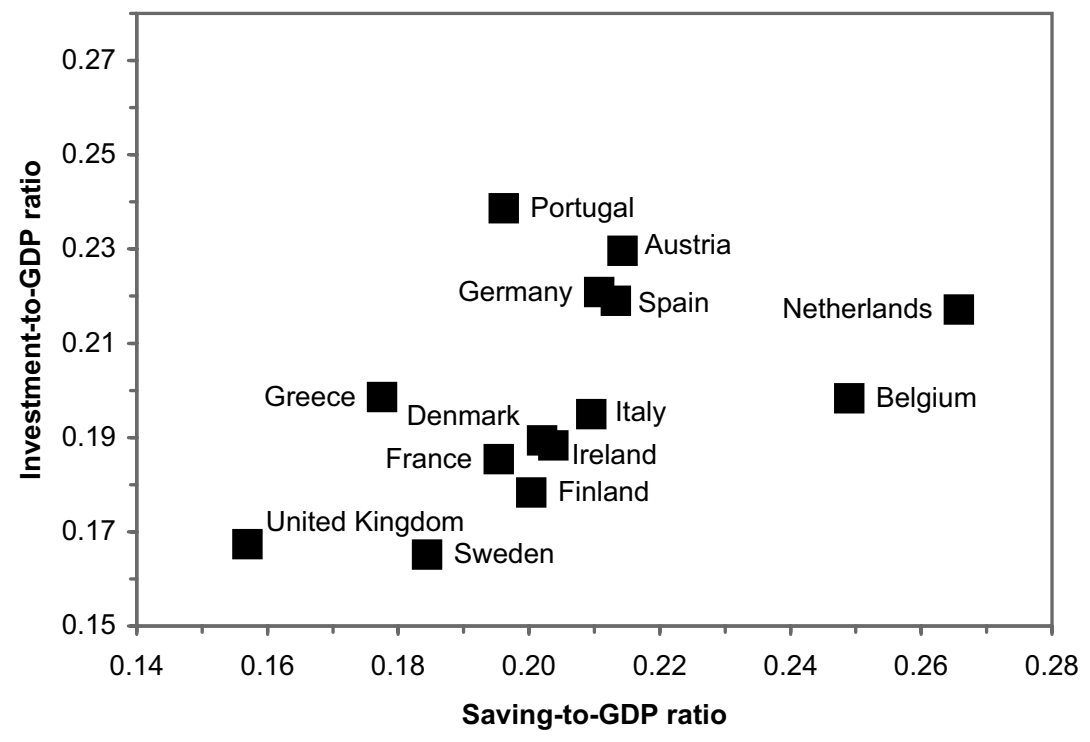

Source: OECD database and Eurostat, own calculations

Figure 2: Saving and Investment Shares of GDP in the EU-IS Countries, I999-2005

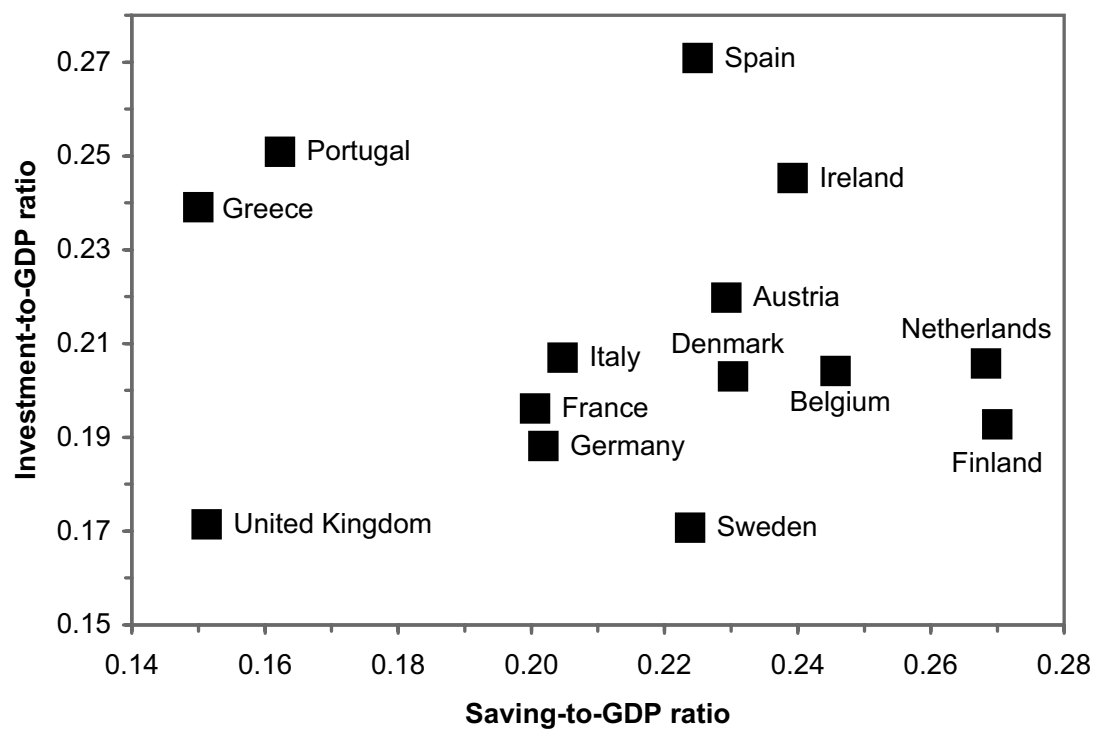

Source: OECD database and Eurostat, own calculations 
Table 4: Ratio of GNP to GDP in the EU-Io Countries

(Percentage Deviation From Group Average, EU-I2 Excluding Ireland and Luxembourg)

\begin{tabular}{l|cccc}
\hline Country & 1980-1991 & 1992-1998 & 1999-2005 & 1980-2005 \\
\hline Austria & -0.55 & -1.01 & -1.25 & -0.86 \\
Belgium & 0.11 & 1.69 & 1.84 & 0.98 \\
Finland & -1.83 & -3.47 & -0.33 & -1.85 \\
\hline France & 0.57 & 0.63 & 1.22 & 0.77 \\
\hline Germany & 0.99 & -0.32 & -0.53 & 0.26 \\
Greece & 2.50 & 3.04 & 0.08 & 1.96 \\
Italy & -0.38 & -1.25 & -0.39 & -0.59 \\
Netherlands & 1.15 & 0.58 & 1.77 & 1.15 \\
\hline Portugal & -3.43 & -0.64 & -1.57 & -2.18 \\
\hline Spain & 0.87 & 0.76 & -0.91 & 0.37 \\
\hline
\end{tabular}

Source: OECD database, own calculations

(1992-1998 and 1999-2005), and for the whole period for which data are available consistently (1980-2005).

The data in table 4 illustrate some interesting patterns. A first group of countries have negative percentage deviations from the EU-Io average GNP-to-GDP ratio throughout the whole period $1980-2005$, indicating that they have been benefiting from net capital inflows from the rest of the EU-IO - either in the form of bank deposits borrowed and thereby owned in some foreign currency areas (prior to the 1999 monetary union) as a result of FDI (see previous section), or in the form of bank deposits recorded in the homecountry banking system (after joining the Euro area) as a result of economic transactions pertaining to the capital account of their balance of payments. This group of countries includes Austria, Finland, Italy, and Portugal. By contrast, other countries, namely, Belgium, France, Greece, the Netherlands, and to some extent Spain, have been experiencing net capital outflows over the same period, which means higher net factor income inflows and therefore an above-average GNP-to-GDP ratio. Interestingly enough, Germany has switched position, and notably moved from having a net capital outflow in the I980-I99I period (but with only a 0.99 percentage deviation from the EU-Io average) to having a net capital inflow in the $1992-1998$ period (-0.32) and furthermore so once in the Euro area (-0.53). The associated outflow of factor income may be partly mirrored by the important reduction of the (adjusted) wage share that occurred in Germany after it disposed of the Deutsche Mark and hence lost its monetary sovereignty - surrendering monetary policy decisions to the European Central Bank (ECB) - which made Germany more competitive on product markets owing to the sluggish evolution of its unit labour costs (Rochon/Rossi 2006: IO5, table 2). 
This situation and the underlying capital flows between EMU countries parallel serious current account imbalances across the EU-I2 (table 5). As Hein/Truger (2006: 8-9) point out in this respect, nominal unit labour costs in Germany have grown at very low rates, which have improved price competitiveness and profitability of German firms and have made German net exports almost quadruple between $200 \mathrm{I}$ and $2005 .{ }^{10} \mathrm{O}$ wing to the importance of intra-Euro-area trade, increasing German export surpluses have increased current account deficits for a number of other Euro area countries. All these imbalances across Euroland are likely to push its member countries to introduce deflationary wage policies to compete with Germany, increasing deflationary pressures across the EMU.

Table 5: Current Account Balance as a Percentage of GDP, EU-I2 Countries, I999-2005

\begin{tabular}{l|rrrrrrrc}
\hline Country & 1999 & 2000 & 2001 & 2002 & 2003 & 2004 & 2005 & $1999-2005$ \\
\hline Austria & -3.2 & -2.5 & -1.9 & 0.3 & -0.2 & 0.2 & 1.1 & 0.5 \\
Belgium & 5.1 & 3.9 & 3.9 & 4.8 & 4.2 & 3.4 & 2.5 & 4.0 \\
Finland & 6.3 & 7.5 & 7.1 & 7.5 & 4.0 & 5.1 & 4.9 & 6.1 \\
\hline France & 2.9 & 1.4 & 1.6 & 1.0 & 0.4 & -0.4 & -1.6 & 1.0 \\
Germany & -1.2 & -1.6 & 0.2 & 2.2 & 2.1 & 3.8 & 4.0 & 2.5 \\
Greece & -4.2 & -8.8 & -8.1 & -7.5 & -7.2 & -6.4 & -6.3 & -6.3 \\
Ireland & 0.3 & -0.4 & -0.7 & -0.9 & 0 & -0.8 & -2.7 & -0.8 \\
Italy & 0.7 & -0.5 & -0.1 & -0.8 & -1.3 & -0.9 & -1.6 & -0.4 \\
Luxembourg & 8.9 & 13.7 & 9.0 & 11.6 & 6.8 & 11.1 & 11.8 & 10.4 \\
Netherlands & 3.9 & 2.0 & 2.5 & 2.6 & 5.7 & 9.4 & 7.7 & 4.8 \\
Portugal & -8.5 & -10.7 & -9.5 & -6.8 & -5.5 & -7.8 & -9.2 & -9.2 \\
Spain & -2.9 & -4.0 & -3.9 & -3.3 & -3.6 & -5.3 & -7.4 & -7.4 \\
\hline
\end{tabular}

Source: OECD database, own calculations

Further, as current account imbalances are mirrored by capital account imbalances that change the net-debtor/net-creditor position of a country, and hence the associated net factor income flows, there is an increasing divergence between the value of output produced within a given EMU member country and the total amount of income earned and of bank deposits owned by its residents. Clearly, for those Euroland countries that are recording net capital inflows from other EMU countries, a fraction of their bank deposits are the result of foreign production. By contrast, for those Euro area countries that are recording net capital outflows to the rest of Euroland, a fraction of the income earned and the relevant bank deposits are lost for local consumption, therefore also for local employment and growth, as bank deposits are eventually spent for consumption purposes - perhaps after

Io This is associated with net capital flows from Germany to its net importing partner countries within the EMU, which will increase the GNP-to-GDP ratio of Germany in the near future. I thank Eckhard Hein for pointing this out to me. 
a series of purely financial transactions - as explained by Keynes. ${ }^{\text {II }}$ To be sure, if there is a lack of consumption (because of net capital outflows, that is to say, bank deposits leaving the country to be spent in some other part of Euroland), then those firms residing in this country will sooner or later leave it, or will at least cut back on employment - unless these same firms produce export goods. Indeed, short-term capital flows between countries pertaining to the same currency area are largely triggered by financial speculation, whilst longterm capital flows are likely to depend more on current account imbalances, which lead businesses to invest in those countries within which sales volumes are increasing for both domestic and foreign reasons, that is to say, into which bank deposits are being spent from the rest of the currency area. If so, then countries recording net capital inflows are likely to observe an upward pressure on their measured rates of inflation, as the incoming bank deposits from other countries in the EMU will be spent, sooner or later, on the local market for produced real goods and services. By contrast, as pointed out above, those EMU member countries that are losing bank deposits to the benefit of the rest of Euroland will observe an increase in local unemployment rates, as firms are unable to sell their production fully and therefore record soaring inventories. ${ }^{\mathrm{I2}}$ Both these cases will pose a problem for the EMU member countries as well as for their economic policy makers, an issue that a »one-size-fits-all« monetary policy cannot solve as we shall see later.

Indeed, free international capital flows have several implications for the currency area as a whole, as well as for its member countries. They mean that capital can really move freely within that currency area, as a result of foreign trade, FDI, or financial speculation, which move bank deposits between countries that share the same currency and a unified interbank settlement system. If we consider the rationale for FDI, for instance, the yield differentials between countries in the same currency area lead to capital flowing to those member countries where the return on investment is highest within that area. (In fact, there are other parameters that enter into consideration for an investor's decision, such as "country risk", so that the expected return on investment is actually not the only magnitude that matters in this respect.) It is precisely this form of investment, by means of which capital moves from one country to another within the same monetary space, that might lead or at least add to real economic disturbances across a currency area.

Empirical evidence at the EU level shows indeed that capital moves from the regions of lesser to those of higher productivity growth, which, within the EMU, means at the time of writing from the centre to the Western periphery of Euroland. Germany is a case in point. ${ }^{13}$ Whilst FDI figures for 2005 are soaring for countries such as Ireland and Spain

II "Human effort and human consumption are the ultimate matters from which alone economic transactions are capable of deriving any significance; and all other forms of expenditure only acquire importance from their having some relationship, sooner or later, to the effort of producers or to the expenditure of consumers" (Keynes 1930: 120-I2I).

I2 See tables 6, 7, and 9 (pp. 323, 325).

I3 Germany is a high productivity country, but in the Western periphery of Euroland productivity growth is, on average, higher: there is a sort of catching-up effect, which makes Germany a country less attractive for FDI, as the return on (productive) investment is not as high as, say, in Spain. 
compared to 1999, Germany has been suffering from the opposite phenomenon after it abandoned its local currency to adopt the euro: From 1999 to 2005, Germany has been losing a significant amount of FDI, so much so that a number of FDI flows have been reversed and are now leaving Germany, to be redirected to some peripheral countries within the Euro area - even though Germany still remains an important recipient of FDI flows. ${ }^{14}$ In other words, capital tends to flee from France, Germany, and Italy, towards the periphery of the Euro area, which includes Finland, Ireland, and Spain (Greece to some extent). ${ }^{\text {is }}$ This is much likely to increase economic divergence between these two EMU "regions", the geographical centre of Euroland losing some percentage points of economic growth and employment to the benefit of the Western periphery of the EMU (tables 6 and 7). To be sure, unemployment figures have increased in those countries that have been suffering most from net capital outflows, within which fiscal policy has been proving insufficient to curb this trend in the rate of unemployment - by increasing public expenditures and/or by reducing tax rates, in order to attract foreign firms and capital inflows -, owing largely to the fiscal criteria of the Treaty on the EU and of the Stability and Growth Pact (see Jespersen 2004, Hein/Truger 2005a and 2005b, and the references cited therein with respect to fiscal issues).

Now, the financial structure of the capital accumulated in a country before it joined the EMU plays an important role in determining the amount and direction of capital flows once this country is within Euroland. Indeed, fixed capital has to be amortised, as wear and tear diminish its use value, and technical progress requires new investment goods to be produced and put to use. Amortisation rates are usually determined according to the economical rather than to the physical duration of a capital good. This duration depends on the pace of technical progress, and on the cost as well as availability of investment funds (Keynes's finance motive). If the capital accumulated by firms of a given country in the EMU has been financed by, say, selling long-term bonds prior to monetary union, and if these securities are remunerated at a rate of interest higher than the EMU average rate of interest, then these firms suffer a loss of competitiveness once their country fully participates in the EMU, as the capital accumulated within them has to be amortised at a cost higher than for the rest of the EMU firms. This problem does not disappear once a country joins Euroland. As a matter of fact, nominal long-term interest rates still differ although to a lesser extent than they used to differ before monetary union - between its member countries over the period 1999-2006 (table 8, p. 324). Most important, owing to

I4 Although incomplete, FDI statistics show rather clearly that the core countries of Euroland are losing ground with respect to some countries at the Western periphery of the Euro area. In particular, Germany is recording a series of FDI flows with a negative sign, which indicates disinvestment, although FDI flows go in both directions for any EMU member country considered. The relevant matrixes with Eurostat data are available on demand from the author.

I5 Greece has been reducing the income gap with the rest of Euroland, owing in particular to the Olympic Games that took place in Athens in 2004. In fact, outside its capital town, Greece has not benefited much from joining the Euro area in terms of economic growth and development. 
Table 6: Annual Growth Rates of Real GDP in the EU-I2 Countries (\%), I999-2008

\begin{tabular}{l|cccccccccc}
\hline Country & 1999 & 2000 & 2001 & 2002 & 2003 & 2004 & 2005 & 2006 & 2007 & 2008 \\
\hline Austria & 3.3 & 3.4 & 0.8 & 0.9 & 1.1 & 2.4 & 2.0 & 3.1 & 2.6 & 2.1 \\
\hline Belgium & 3.4 & 3.7 & 0.8 & 1.5 & 1.0 & 3.0 & 1.1 & 3.1 & 2.3 & 2.2 \\
Finland & 3.9 & 5.0 & 2.6 & 1.6 & 1.8 & 3.7 & 2.9 & 4.9 & 3.0 & 2.6 \\
\hline France & 3.2 & 4.0 & 1.9 & 1.0 & 1.1 & 2.3 & 1.2 & 2.2 & 2.3 & 2.1 \\
Germany & 2.0 & 3.2 & 1.2 & 0.0 & -0.2 & 1.2 & 0.9 & 2.7 & 1.2 & 2.0 \\
\hline Greece & 3.4 & 4.5 & 5.1 & 3.8 & 4.8 & 4.7 & 3.7 & 3.8 & 3.7 & 3.7 \\
Ireland & 10.7 & 9.4 & 5.8 & 6.0 & 4.3 & 4.3 & 5.5 & 5.3 & 5.3 & 4.3 \\
\hline Italy & 1.9 & 3.6 & 1.8 & 0.3 & 0.0 & 1.2 & 0.1 & 1.9 & 1.4 & 1.4 \\
Luxembourg & 8.4 & 8.4 & 2.5 & 3.8 & 1.3 & 3.6 & 4.0 & 5.5 & 4.5 & 4.2 \\
\hline Netherlands & 4.7 & 3.9 & 1.9 & 0.1 & 0.3 & 2.0 & 1.5 & 2.9 & 2.9 & 2.6 \\
Portugal & 3.9 & 3.9 & 2.0 & 0.8 & -1.1 & 1.2 & 0.4 & 1.2 & 1.5 & 1.7 \\
\hline Spain & 4.7 & 5.0 & 3.6 & 2.7 & 3.0 & 3.2 & 3.5 & 3.9 & 3.4 & 3.3 \\
\hline EU-12 & 3.0 & 3.9 & 1.9 & 0.9 & 0.8 & 2.0 & 1.4 & 2.6 & 2.1 & 2.2 \\
\hline
\end{tabular}

Note: Data for 2006, 2007 and 2008 are European Commission's forecasts.

Source: Eurostat

Table 7: Annual Unemployment Rates in the EU-I2 Countries (\%), I999-2006

\begin{tabular}{l|rrrrrrrr}
\hline Country & 1999 & 2000 & 2001 & 2002 & 2003 & 2004 & 2005 & 2006 \\
\hline Austria & 3.9 & 3.6 & 3.6 & 4.2 & 4.3 & 4.8 & 5.2 & 4.8 \\
\hline Belgium & 8.5 & 6.9 & 6.6 & 7.5 & 8.2 & 8.4 & 8.4 & 8.3 \\
\hline Finland & 10.2 & 9.8 & 9.1 & 9.1 & 9.0 & 8.8 & 8.4 & 7.7 \\
\hline France & 10.5 & 9.1 & 8.4 & 8.7 & 9.4 & 9.6 & 9.6 & 9.0 \\
Germany & 7.9 & 7.2 & 7.4 & 8.2 & 9.0 & 9.5 & 9.5 & 8.4 \\
Greece & 12.0 & 11.2 & 10.7 & 10.3 & 9.7 & 10.5 & 9.8 & n.a. \\
Ireland & 5.7 & 4.2 & 4.0 & 4.5 & 4.7 & 4.5 & 4.3 & 4.4 \\
\hline Italy & 10.9 & 10.1 & 9.1 & 8.6 & 8.4 & 8.0 & 7.7 & n.a. \\
Luxembourg & 2.4 & 2.3 & 2.0 & 2.7 & 3.7 & 5.1 & 4.5 & 4.8 \\
\hline Netherlands & 3.2 & 2.8 & 2.2 & 2.8 & 3.7 & 4.6 & 4.7 & 3.9 \\
Portugal & 4.5 & 4.0 & 4.0 & 5.0 & 6.3 & 6.7 & 7.6 & 7.4 \\
\hline Spain & 12.5 & 11.1 & 10.3 & 11.1 & 11.1 & 10.6 & 9.2 & 8.6 \\
\hline EU-12 & 7.7 & 6.9 & 6.5 & 6.9 & 7.3 & 7.6 & 7.4 & n.a. \\
\hline
\end{tabular}

Source: Eurostat 
the existence and persistence of inflation rate differentials within the Euro area as measured through the Harmonised Index of Consumer Prices (HICP) (table 9), real interest rates are not yet the same across that area. This gives rise to different costs of borrowing for investment projects (table Io), and may also explain some growth differentials in both GDP and employment levels between the EU-I2 countries over the EMU period so far (recall tables 6 and 7 ). As the last column in table Io shows, to date the three most attractive EMU countries in terms of borrowing costs are Ireland, Spain, and Portugal; by way of contrast, the worst ranked in this respect are Finland and Germany, since they have the highest real interest rates, largely because they have the lowest rate of inflation across Euroland over the whole EMU period so far.

Table 8: Long-Term Nominal Interest Rates in the EU-I2 Countries (\%), I999-2006

\begin{tabular}{l|rrrrrrrr}
\hline Country & 1999 & 2000 & 2001 & 2002 & 2003 & 2004 & 2005 & 2006 \\
\hline Austria & 4.68 & 5.56 & 5.07 & 4.97 & 4.15 & 4.15 & 3.39 & 3.80 \\
\hline Belgium & 4.75 & 5.59 & 5.13 & 4.99 & 4.18 & 4.15 & 3.43 & 3.81 \\
\hline Finland & 4.72 & 5.48 & 5.04 & 4.98 & 4.13 & 4.11 & 3.35 & 3.78 \\
\hline France & 4.61 & 5.39 & 4.94 & 4.86 & 4.13 & 4.10 & 3.41 & 3.80 \\
\hline Germany & 4.49 & 5.26 & 4.80 & 4.78 & 4.07 & 4.04 & 3.35 & 3.76 \\
\hline Greece & 6.30 & 6.10 & 5.30 & 5.12 & 4.27 & 4.25 & 3.58 & 4.07 \\
Ireland & 4.71 & 5.51 & 5.01 & 5.01 & 4.13 & 4.08 & 3.33 & 3.74 \\
\hline Italy & 4.73 & 5.58 & 5.19 & 5.03 & 4.25 & 4.26 & 3.56 & 4.05 \\
Luxembourg & n.a. & n.a. & n.a. & n.a. & n.a. & n.a. & n.a. & n.a. \\
\hline Netherlands & 4.63 & 5.40 & 4.96 & 4.89 & 4.12 & 4.09 & 3.37 & 3.78 \\
\hline Portugal & 4.78 & 5.59 & 5.16 & 5.01 & 4.18 & 4.14 & 3.44 & 3.91 \\
\hline Spain & 4.73 & 5.53 & 5.12 & 4.96 & 4.12 & 4.10 & 3.39 & 3.78 \\
\hline
\end{tabular}

Note: Data refer to government bonds with maturities of close to ten years.

\section{Source: Eurostat}

An analogous reasoning holds for those firms whose capital stock is obsolete owing to technological progress: in this case, these firms will have to speed up the amortisation process of their fixed capital stock, to replace it with some newer, more technological instrumental goods. If so, then these firms will need to replace their capital stock more rapidly than the rest of the EMU businesses, in which case the resulting increase in their production costs will reduce their competitiveness, and hence lead them to cut back on production and employment. This limits economic growth and increases unemployment rates, particularly within those EMU countries, like Germany and other core countries of Euroland, that suffer most from the anti-inflationary policy that the ECB has been implementing so far, as revealed by the evolution of the adjusted wage share across the EMU (see Rochon/Rossi 2006 in this respect). 
Table 9: Inflation Rates in the EU-I2 Countries (\%), I999-2006

\begin{tabular}{l|ccccccccc}
\hline Country & 1999 & $\mathbf{2 0 0 0}$ & $\mathbf{2 0 0 1}$ & $\mathbf{2 0 0 2}$ & $\mathbf{2 0 0 3}$ & $\mathbf{2 0 0 4}$ & $\mathbf{2 0 0 5}$ & $\mathbf{2 0 0 6}$ & 1999-2006 \\
\hline Austria & 0.5 & 2.0 & 2.3 & 1.7 & 1.3 & 2.0 & 2.1 & 1.7 & 1.7 \\
Belgium & 1.1 & 2.7 & 2.4 & 1.6 & 1.5 & 1.9 & 2.5 & 2.3 & 2.0 \\
Finland & 1.3 & 2.9 & 2.7 & 2.0 & 1.3 & 0.1 & 0.8 & 1.3 & 1.5 \\
France & 0.6 & 1.8 & 1.8 & 1.9 & 2.2 & 2.3 & 1.9 & 1.9 & 1.8 \\
Germany & 0.6 & 1.4 & 1.9 & 1.4 & 1.0 & 1.8 & 1.9 & 1.8 & 1.5 \\
Greece & 2.1 & 2.9 & 3.7 & 3.9 & 3.4 & 3.0 & 3.5 & 3.3 & 3.2 \\
Ireland & 2.5 & 5.3 & 4.0 & 4.7 & 4.0 & 2.3 & 2.2 & 2.7 & 3.5 \\
Italy & 1.7 & 2.6 & 2.3 & 2.6 & 2.8 & 2.3 & 2.2 & 2.2 & 2.3 \\
Luxembourg & 1.0 & 3.8 & 2.4 & 2.1 & 2.5 & 3.2 & 3.8 & 3.0 & 2.7 \\
Netherlands & 2.0 & 2.3 & 5.1 & 3.9 & 2.2 & 1.4 & 1.5 & 1.7 & 2.5 \\
Portugal & 2.2 & 2.8 & 4.4 & 3.7 & 3.3 & 2.5 & 2.1 & 3.0 & 3.0 \\
Spain & 2.2 & 3.5 & 2.8 & 3.6 & 3.1 & 3.1 & 3.4 & 3.6 & 3.1 \\
\hline
\end{tabular}

Note: Data refer to the year-to-year percentage variation of the HICP.

Source: Eurostat

Table 10: Average Long-Term Real Interest Rates in the EU-I2 Countries (\%), I999-2006

\begin{tabular}{l|cccc}
\hline Country & $\begin{array}{c}\text { Average long- } \\
\text { term nominal } \\
\text { interest rate }\end{array}$ & $\begin{array}{c}\text { Average inflation } \\
\text { rate (HICP) }\end{array}$ & $\begin{array}{c}\text { Average long- } \\
\text { term real } \\
\text { interest rate }\end{array}$ & $\begin{array}{c}\text { Rank in terms of } \\
\text { borrowing costs }\end{array}$ \\
\hline Austria & 4.47 & 1.70 & 2.77 & 9 \\
\hline Belgium & 4.50 & 2.00 & 2.50 & 7 \\
\hline Finland & 4.45 & 1.50 & 2.95 & 11 \\
\hline France & 4.41 & 1.80 & 2.61 & 8 \\
Germany & 4.32 & 1.50 & 2.84 & 10 \\
\hline Greece & 4.87 & 3.20 & 1.65 & 4 \\
\hline Ireland & 4.44 & 3.50 & 0.98 & 6 \\
\hline Italy & 4.58 & 2.30 & 2.24 & n.a. \\
\hline Luxembourg & n.a. & 2.70 & n.a. & 5 \\
\hline Netherlands & 4.41 & 2.50 & 1.89 & 3 \\
\hline Portugal & 4.53 & 3.00 & 1.53 & 2 \\
\hline Spain & 4.47 & 3.10 & 1.40 & \\
\hline
\end{tabular}

Source: Tables 8 and 9, own calculations 


\section{Concluding Remarks}

In light of the existing, and persistent, inflation rate differentials between EMU member countries at the time of writing, and the ensuing different costs of borrowing, it seems difficult, if not impossible, for the single monetary policy of the ECB to do justice, at the same time, to the different needs of all countries within Euroland. This might bring about tensions in the monetary policy strategy of the ECB as well as in its decision making process, exacerbated by the home-country bias that might affect the decisions taken by the members of its Governing Council, as these members today are still part of their home country administration. ${ }^{16}$ The single interest rate policy oriented towards the needs of the Euro area as a whole might in particular be hampered by extensive country heterogeneity as regards the degree of capitalisation of their production systems as well as by massive capital flows across that area. Put at the same monetary level as that of the most capitalised as well as the most advanced technological production systems, the less-advanced and slowgrowing countries in the EMU experience a number of firms' closing down, while many investments are being diverted towards more competitive regions. Further, with heterogeneous cross-country responses, the single monetary policy itself is rather likely to induce idiosyncratic business cycles across Euroland (Suardi 200I). This amounts to saying that the GDP growth gap between the two groups of EMU countries (that is, fast-growing and slow-growing Euro-area countries) might increase over the next years, which could indeed slow down the economy of the whole Euro area rather than doing the opposite, owing notably to the deflationary pressures pointed out in this paper. Also, if the ECB were to intervene in an attempt to counteract a major economic shock in one of the large(st) EMU countries, it might indeed increase cyclical divergence between these countries, thus hindering synchronisation of the business cycle across Euroland.

Now, owing largely to the fiscal deficit-to-GDP ceiling of three percent enshrined in the Maastricht Treaty and in the Stability and Growth Pact, national fiscal policies cannot really address the unemployment problem arising from free capital mobility within the Euro area. At the time of writing, the number of Euroland countries that fail to meet the fiscal requirements set out in Maastricht, and enforced in Amsterdam, is notably a sign that these requirements represent a straitjacket, which constrains the fiscal policy efforts that a country ought to undertake in order to fight against capital flight towards another Euroarea country. In this situation, total aggregate demand is deficient, and this deflationary situation leads to firms cutting back on employment in a number of Euro-area countries, particularly at the geopolitical core of the EMU, with no macroeconomic policy available in the present institutional setting to curb this worrying trend. Clearly, a reform of the institutional design and policy strategy of the ECB is a priority that has to be put on the EU agenda. In particular, an intergovernmental conference at the EU level has to limit some-

I6 This bias can be eradicated if appointment to the ECB Governing Council does not consider nationality, and is moreover the result of a democratic election, such as it occurs to date for the European Parliament (Rossi 2008). 
how the ECB independence in monetary policy making, considering as a starting point the framework within which the Bank of England currently operates - in which there is a (timid) coordination between fiscal and monetary policies, oriented also towards output stabilisation (see Hein/Truger 2005c for analytical elaboration with respect to the EMU case). Let us hope that both economists and policy makers will follow suit, to provide a definitive solution to the current crisis in European economic integration.

\section{References}

Bayoumi, Tamim/Sarno, Lucio/Taylor, Mark P. (I999): European Capital Flows and Regional Risk, in: The Manchester School, Vol. 67, No. I, pp. 2I-38

Coakley, Jerry/Kulasi, Farida/Smith, Ron (1998): The Feldstein-Horioka Puzzle and Capital Mobility: A Review, in: International Journal of Finance and Economics, Vol. 3, No. 2, pp. I69-I88

Edwards, Sebastian (1999): International Capital Flows and the Emerging Markets: Amending the Rules of the Game, in: Little, Jane S./Olivei, Giovanni P. (eds.), Rethinking the International Monetary System, Boston: Federal Reserve Bank of Boston, pp. 137-I57

Eurostat (online version), URLs: http://epp.eurostat.ec.europa.eu/extraction/evalight/EVAlight. jsp?A=I\&language=en\&root=/theme2/nama/nama_inc_c, http://epp.eurostat.ec.europa. eu/portal/page?_pageid=1996,39140985\&_dad=portal\&_schema=PORTAL\&screen= detailref\&language=en\&product=SDI_MAIN\&root=SDI_MAIN/sdi/sdi_ed/sdi_ed_ inv/sdi_edırı, http://epp.eurostat.ec.europa.eu/portal/page?_pageid=1996,39140985\&_ $\mathrm{dad}=$ portal\&_schema $=$ PORTAL $\&$ screen $=$ detailref\&language $=$ en $\&$ product $=$ sdi_ed \&root=sdi_ed/sdi_ed/sdi_ed_emp/sdi_edI43I, http://epp.eurostat.ec.europa.eu/portal/ page?_pageid=I996,39140985\&_dad=portal\&_schema=PORTAL\&screen=detailref $\&$ language $=$ en $\&$ product $=$ Yearlies_new_economy\&root=Yearlies_new_economy $/ \mathrm{B} / \mathrm{B}_{3} /$ B32/dbci2048, http://epp.eurostat.ec.europa.eu/portal/page?_pageid=1996,39140985\&_ $\mathrm{dad}=$ portal\&_schema $=$ PORTAL $\&$ screen $=$ detailref $\&$ language $=$ en $\&$ product $=S D I$ MAIN\&root=SDI_MAIN/sdi/sdi_ed/sdi_ed_inv/sdi_edı6o

Feldstein, Martin/Horioka, Charles (I980): Domestic Saving and International Capital Flows, in: Economic Journal, Vol. 90, No. 358, pp. 314-329

Fischer, Stanley (2004): Capital Account Liberalization and the Role of the IMF, in: IMF, Essays from a Time of Crisis: The International Financial System, Stabilization, and Development, Cambridge (Mass.)/London: The MIT Press, pp. II7-I33

Goldin, Ian/Reinert, Kenneth A. (2005): Global Capital Flows and Development: A Survey, in: Journal of International Trade and Economic Development, Vol. I4, No. 4, pp. $453-48 \mathrm{I}$

Hein, Eckhard/Truger, Achim (2005a): What Ever Happened to Germany? Is the Decline of the Former European Key Currency Country Caused by Structural Sclerosis or by Macroeconomic Mismanagement?, in: International Review of Applied Economics, Vol. 19, No. I, pp. 3-28 
Hein, Eckhard/Truger, Achim (2005b): European Monetary Union: Nominal Convergence, Real Divergence and Slow Growth?, in: Structural Change and Economic Dynamics, Vol. 16, No. I, pp. 7-33

Hein, Eckhard/Truger, Achim (2005c): Macroeconomic Coordination as an Economic Policy Concept: Opportunities and Obstacles in the EMU, in: Hein, Eckhard/Niechoj, Torsten/ Schulten, Thorsten/Truger, Achim (eds.), Macroeconomic Policy Coordination in Europe and the Role of the Trade Unions, Brussels: European Trade Union Institute, pp. 19-67 Hein, Eckhard/Truger, Achim (2006): Monetary Policy, Macroeconomic Policy Mix and Economic Performance in the Euro Area, IMK (Macroeconomic Policy Institute) Working Paper, No. 6/2006, Düsseldorf: IMK

Hicks, John R. (1974): Capital Controversies: Ancient and Modern, in: American Economic Review, Vol. 64, No. 2, pp. 307-316. Reprinted in: Hicks, John R. (1977): Economic Perspectives: Further Essays on Money and Growth, Oxford: Clarendon Press, pp. I49-165

Innes, A. Mitchell (1913): What Is Money?, in: Banking Law Journal, No. 5, pp. 377-408

Jespersen, Jesper (2004): The Stability Pact: A Macroeconomic Straitjacket!, in: Ljungberg, Jonas (ed.), The Price of the Euro, Basingstoke: Palgrave Macmillan, pp. 45-58

Keynes, John M. (1930): A Treatise on Money, Vol. I: The Pure Theory of Money, London: Macmillan

Keynes, John M. (1936): The General Theory of Employment, Interest and Money, London: Macmillan

Keynes, John M. (1980): The Collected Writings of John Maynard Keynes, Vol. XXV, Activities 1940-1944. Shaping the Post-War World: the Clearing Union, edited by Donald Moggridge, London/New York: Macmillan and Cambridge University Press

Lavoie, Marc (1999): The Credit-Led Supply of Deposits and the Demand for Money: Kaldor's Reflux Mechanism as Previously Endorsed by Joan Robinson, in: Cambridge Journal of Economics, Vol. 23, No. I, pp. IO3-II3

OECD database(onlineversion),URLs:http://www.oecd.org/dataoecd/5/48/2483858.xls, http:// stats.oecd.org/wbos/default.aspx?datasetcode=SNA_TABLE2

Rochon, Louis-Philippe/Rossi, Sergio (2006): The Monetary Policy Strategy of the European Central Bank: Does Inflation Targeting Lead to a Successful Stabilisation Policy?, in: Hein, Eckhard/Heise, Arne/Truger, Achim (eds.), European Economic Policies: Alternatives to Orthodox Analysis and Policy Concepts, Marburg: Metropolis, pp. 87-IIO

Rossi, Sergio (2007): Money and Payments in Theory and Practice, London/New York: Routledge

Rossi, Sergio (2008): Inflation Targeting and Monetary Policy Governance: The Case of the European Central Bank, in: Gnos, Claude/Rochon, Louis-Philippe (eds.), Post-Keynesian Principles of Economic Policy, Vol. 2, Cheltenham/Northampton: Edward Elgar, forthcoming

Rueff, Jacques (1963): Gold Exchange Standard a Danger to the West, in: Grubel, Herbert G. (ed.), World Monetary Reform: Plans and Issues, Stanford/London: Stanford University Press and Oxford University Press, pp. 320-328 
Singh, Ajit (2003): Capital Account Liberalization, Free Long-Term Capital Flows, Financial Crises and Economic Development, in: Eastern Economic Journal, Vol. 29, No. 2, pp. I9I-2I6

Spahn, Heinz-Peter (2006): Geldpolitik: Finanzmärkte, neue Makroökonomie und zinspolitische Strategien, München.

Stiglitz, Joseph E. (2004): Capital-Market Liberalization, Globalization, and the IMF, in: Oxford Review of Economic Policy, Vol. 20, No. I, pp. 57-7I

Suardi, Massimo (200I): EMU Asymmetries in the Monetary Policy Transmission, European Commission Economic Papers, No. 157 
